\title{
Corporate Trade Credit and Inventories: New Evidence of a Tradeoff from Accounts Payable and Receivable.
}

\author{
Spiros Bougheas ${ }^{\#}$, Simona Mateut ${ }^{+}$, Paul Mizen\#* \\ \#School of Economics, University of Nottingham, \\ University Park, Nottingham, NG7 2RD, United Kingdom \\ + Department of Economics, University of Sheffield, \\ 9 Mappin Road, Sheffield, S1 4DT
}

April 2008

\begin{abstract}
Trade credit is an important source of finance for firms and has been well researched, but the focus has been on financial tradeoffs. In this paper we consider the tradeoffs with inventories and develop a simple model that recognises the incentives a firm faces to offer and receive trade credit. Our model identifies the response of accounts payable and accounts receivable to changes in the cost of inventories, profitability, risk and liquidity, and importantly, this influence operates through a production channel. Our results support the model and complement many existing studies focused on explaining the financial terms of trade credit.

JEL classification: G31, G32

Keywords: Trade Credit, Inventories

${ }^{*}$ Corresponding author: spiros.bougheas@nottingham.ac.uk. We acknowledge beneficial comments from participants at the reaserch day organised by the Centre for Finance and Credit Markets, University of Nottingham, September 2007. Any remaining errors
\end{abstract} are our own. 


\section{Introduction}

Trade Credit is a major element of corporate finance. Rajan and Zingales (1995) document that the volume of trade credit in aggregate was a significant part (17.8\%) of total assets for all American firms in the early 1990s. In Germany, France and Italy, trade credit represents more than a quarter of total corporate assets, while in the United Kingdom 70 per cent of total short term debt (credit extended) and 55 per cent of total credit received by firms is made up of trade credit (Kohler, Britton and Yates, 2000; Guariglia and Mateut, 2006). Accordingly, trade credit has been thoroughly researched but the research has focused mainly on the financial substitutes and complements to trade credit by asking what is the advantage of obtaining credit directly from sellers compared to other (often cheaper) forms of credit such as bank loans. Atanasova and Wilson (2004) find that to avoid bank credit rationing, smaller UK companies increase their reliance on inter-firm credit and Guariglia and Mateut (2006) suggest the uptake of trade credit weakens the credit channel as firms substitute trade finance for bank loans when monetary policy tightens.

The literature provides explanations for uptake or offer of trade credit based on informational asymmetries (Smith, 1987, and Biais and Gollier, 1997), discrimination arguments (Brennan, Maksimovic and Zechner, 1988), monitoring advantages (Jain, 2000 and Mateut, Bougheas and Mizen, 2006), insurance (Cunat, 2007), product quality (Lee and Stove, 1993 and Long, Malitz and Ravid, 1994) bankruptcy (Frank and Maksimovic, 2004 and Wilner, 2000) opportunistic behavior (Burkart and Ellingsen, 2004) and externalities (Daripa and Nilsen, 2005). Empirical studies explore the relationships between accounts payable and accounts receivable and other balance sheet variables to corroborate or refute these theories and examine in detail the terms and conditions of trade credit. ${ }^{1}$

This literature has been informative, but it does not address another important tradeoff that the firm faces between inventories and trade credit which is the focus of this paper. ${ }^{2}$ Firms produce goods for sale, hold in-

\footnotetext{
${ }^{1}$ See for example, Mian and Smith (1992), Rajan and Zingales (1995), Petersen and Rajan (1997), Ng, Smith and Smith (1999), Demirguc-Kunt and Maksimovic (2002), Alphonse, Ducret and Severin (2003), Fisman and Love (2003), Giannetti (2003), Preve (2003), Burkart, Ellingsen and Giannetti (2005), Cunningham (2004) and Love, Preve and Sarria-Allende (2005).

${ }^{2}$ Two well cited theories of trade credit by Biais and Gollier (1997) on signalling and Burkart and Ellingsen (2004) on diversion, we find that both focus on the relationship between trade credit and bank loans but neither one explicitly analyzes the role of inventories. Operations research by contrast has recognized the link between trade credit and inventories but with an interest in inventory management per se. While the inventory literature acknowledges the interaction between trade credit and inventories for optimal control, it is less interested in the economic question of how a firm might consider tradeoffs between greater overall sales and lower inventory costs versus lower liquidity. In this paper, we take a closer look at these trade-offs by proposing a theory and offering some ev-
} 
ventories of goods that were produced but unsold at a cost, and, critically, offer and receive trade credit in the middle of a credit chain. Therefore, producers facing an uncertain demand for their products face an incentive to extend trade credit to their financially constrained customers in order to promote sales rather than accumulate costly inventories of finished goods. This incentive is limited by only by the need to obtain liquidity to meet their own obligations, producers might readily offer trade credit on appropriate terms to enhance cash sales and boost demand. This trade-off has not been fully explored in the economics literature.

We view the analysis of the tradeoff between inventories and trade credit as complementary to theories that address financial aspects of trade credit. Some early work on trade credit following a transactions costs approach has analyzed the trade-offs between the costs of financial transactions and the costs related to the exchange of goods (see, for example, Nadiri (1969), Schwartz (1974), Ferris (1981) and Emery (1987)). Only Emery (1987) considers explicitly the trade-off between trade credit and inventories but does so within a deterministic variable demand framework. More recently, Daripa and Nilsen (2005) have theoretically examined how this trade-off influences the terms of trade credit agreements. In their model suppliers offer trade credit as an incentive to buyers to hold higher inventories - shifting inventories from seller to buyer. The underlying rationale for trade credit has some similarities with ours when we consider a firm that lies in the middle of a credit chain, since suppliers reduce inventories by offering trade credit and firms that accept trade credit from their suppliers and thus increase their inventories are also in the position to offer trade credit to their own customers. In fact, the predictions of their model with respect to the effects of changes in inventories and profit margins on the levels of trade credit are the same as ours.

We present a very stylized two-period stochastic demand model that provides directly testable predictions on the response of accounts payable and accounts receivable to changes in the cost of inventories, profitability, risk and liquidity, which operate by influencing production. Even the influence of bank loans on trade credit operates by allowing greater production, inventories and sales, financed in part through credit. We directly test the predictions of our model using GMM estimates in first differences on an unbalanced panel of UK firms drawn from FAME that includes larger FTSE-quoted firms and those on the smaller AIM/OFEX exchange, as well as unquoted firms ${ }^{3}$. The results show a direct influence of inventories on accounts receivable but a neglible effect on accounts payable even after con-

idence. See Dobb and Silver (2006) who provide an extensive review of the literature that explores the advantages of alternative inventory control methods subject to the availability of trade credit.

${ }^{3}$ The source is the FAME (Bureau van Dijk) database collected by Electronic Publishing . See http://fame.bvdep.com. 
trolling for firms characteristics such as liquidity, profitability and risk, and allowing for scale of bank borrowing. The effect of inventories on trade credit is dependent on firm size, as inventory holding costs fall with size.

In the following section we develop a simple model that captures the trade-off between trade credit and inventory under stochastic demand. In section 3 , we present our empirical work and in the final section we conclude.

\section{Inventories and Trade Credit}

Consider the following 2-period snapshot in the life of a single-product firm that belongs in a competitive industry and lies in the middle of a trade credit chain. In period 1, when the firm decides its level of production it faces uncertainty about the price for its product. The uncertainty can be related to both firm-specific shocks and market instability. Let $A$ denote the state of the world in period 2 and $p(A)$ the corresponding price, where $p^{\prime}(A)>0$. Furthermore, let $\hat{q}$ denote its level of production in period 1 and $q(\leq \hat{q})$ denote sales in period $2 .{ }^{4}$ Given that potential buyers are financially constrained in period 2 the firm faces the following trade-off. It can avoid holding costly inventories by extending trade credit to its customers, but trade credit is itself costly as the firm foregoes cash with which to repay its own creditors. By offering goods on credit the firm is trading-off potential future cash sales opportunities. We also assume that on average inventories are sold on discount. The following maximization program captures this trade-off and solves for the optimal level of sales in period 2 .

$$
\max _{q}\left\{p(A) q+p^{E}(\hat{q}-q)-v(\hat{q}-q, x)-r\left(p(A) q-c_{R}(m)\right)\right\}
$$

The first term represents sales in period 2 (both on cash and on trade credit) while the second term captures future revenues from the sale of inventories, where $p^{E}$ denotes the expected future price. $v(\cdot, \cdot)$ represents the holding cost of inventories, $\hat{q}-q$, and $x$ is a shift parameter that captures other factors that influence the cost of inventories. The final term $r(\cdot)$ captures the cost of extending trade credit (accounts receivable) that depends on the amount of trade credit extended, which in turn is equal to sales minus cash receipts (assumed here to be directly related to the level of liquidity, $m$ ). ${ }^{5}$ We impose the following restrictions on these functions: $v_{1}>0, v_{11}>0$, $v_{2}>0, v_{12}>0,1>r^{\prime}>0, r^{\prime \prime}>0$ and $c_{R}^{\prime}>0$. Thus, we assume that inventory costs are convex in the level of inventories and that the shift parameter represents a firm characteristic that is associated with higher inventory costs. We further assume that costs related to extending trade

\footnotetext{
${ }^{4}$ In a multi-period model sales would be restricted by the sum of production and past inventories. For our purposes, setting past inventories equal to zero is inconsequential.

${ }^{5}$ Accounts receivable, defined as sales minus cash receipts is directly observable in the data.
} 
credit (cost of receivables) are increasing at an increasing rate with the level of trade credit reflecting costs related to lack of cash (higher demand for expensive accounts payable) and higher expected bankruptcy costs. Finally, firms that target a higher liquidity will be less willing to offer trade credit.

The f.o.c. of the above program is

$$
p(A)-p^{E}+v_{1}-p(A) r^{\prime}=0
$$

that implicitly provides a solution for desired sales as a function of the state of the world, $q(A)$. Actual sales are restricted by production, thus optimal sales, $q^{*}$, are given by

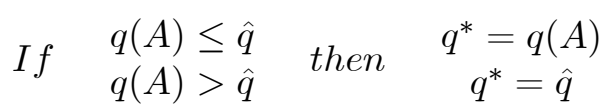

The implicit function theorem implies that

$$
\frac{d q}{d A}=\frac{p^{\prime}(A)\left(1-r^{\prime}-r^{\prime \prime} p(A) q\right)}{v_{11}+(p(A))^{2} r^{\prime \prime}}
$$

where the second-order condition for a maximum implies that the denominator is positive. Whether sales increase with the state of demand would depend on the cost of extending trade credit. As long as the corresponding function is not too convex ( $r_{11}$ is low) an increase in the state of demand would imply higher sales. ${ }^{6}$ From now on we assume the more plausible case $\frac{d q}{d A}>0$. Then, together, (2) and (3) imply that there exists a state of the world $\hat{A}$ such that $\hat{q}=q(\hat{A})$. In low demand states, $A<\hat{A}$, the firm sells less than its output and thus inventories increase while in high demand states, $A>\hat{A}$, the firm offers sufficient trade credit so that its entire output is sold.

Next, we solve for the optimal level of output in period 1. Let $z$ denote the constant marginal cost. The firm uses its liquidity, $m$, to pay part of its cost of production, $z \hat{q}$, and to cover the rest it borrows from its suppliers. ${ }^{7,8}$ In period 1 the firm solves the following program

$$
\begin{aligned}
& \max _{\hat{A}} \int_{A<\hat{A}}\left[\begin{array}{c}
p(A) q(A)+p^{E}(q(\hat{A})-q(A))- \\
v(q(\hat{A})-q(A), x)-r\left(p(A) q(A)-c_{R}(m)\right)
\end{array}\right] f(A) d A+ \\
& \int_{A>\hat{A}}\left[p(A) q(\hat{A})-r\left(p(A) q(\hat{A})-c_{R}(m)\right)\right] f(A) d A-z q(\hat{A})- \\
& b\left(z q(\hat{A})-c_{P}(m)\right)
\end{aligned}
$$

\footnotetext{
${ }^{6}$ The reason that the sign is ambiguous is because an increase in the state of demand (higher $A$ which implies a higher $p$ ) will boost revenues even if sales stay the same. But this would imply that the firm would have to offer more trade credit. If the cost of the latter is too high it might decide to lower sales.

${ }^{7}$ Notice that $m$ denotes both liquidity in period 2 that includes cash receipts and available liquidity in period 1. This simplification is deemed neccessary because of data constraints. Trade credit is held on average for periods much shorter than the yearly frequency of our data. Thus, $m$ captures the average liquidity over a 12-month period.

${ }^{8}$ Of course, firms have other short-term financial options that for the moment we ignore so that we can concentrate on the trade-off between trade credit and inventories.
} 
where the last term, $b(\cdot)$, captures the cost of holding accounts payable which are equal to the cost of production, $z \hat{q}$, minus cash payments $c_{P}(m)$ (where we assume that $c_{P}^{\prime}>0$; i.e. firms with higher liquidity avoid costly accounts payable) and $f(\cdot)$ is the density function of the distribution of $A$. We assume that $b^{\prime}>0$ and $b^{\prime \prime}>0$ and they capture costs that might be related to the deterioration of the balance sheet as trade credit expands.

The f.o.c. of the period-1 program is

$$
\int_{A<\hat{A}}\left[p^{E}-v_{1}\right] f(A) d A+\int_{A>\hat{A}}\left[p(A)\left(1-r^{\prime}\right)\right] f(A) d A-z\left(1+b^{\prime}\right)=0
$$

Higher production increases inventories in low demand states and consequently increases both inventory costs and future revenues (first term) and revenues in high demand states (second term). The last term captures the effect of a marginal increase in output on production and financing costs. The above first-order condition implicitly provides a solution for optimal output as a function of various exogenous variables.

For our comparative statics below the total derivative of (4), D, with respect to $\hat{A}$, will be useful:

$$
D \equiv-\left[\int_{A<\hat{A}} v_{11} f(A) d A+\int_{A>\hat{A}}(p(A))^{2} r^{\prime \prime} f(A) d A+z^{2} b^{\prime \prime}\right] d \hat{q}<0
$$

where (1) was used for simplifying the above derivation. The comparative statics of our model that we are interested in are the effects of changing a number of exogenous variables on the levels of accounts payable

$$
P \equiv z q(\hat{A})-c_{P}(m)
$$

and (expected) accounts receivable

$$
R \equiv \int_{A<\hat{A}} p(A) q(A) f(A) d A+\int_{A>\hat{A}} p(A) q(\hat{A}) f(A) d A-c_{R}(m)
$$

One useful observation is that a change in $\hat{A}$ will affect both accounts payable and accounts receivable in the same direction. As production increases, for a given level of liquidity, both trade credit terms go up.

\subsection{Cost of Holding Inventories}

Inventory costs, such as warehousing and stockout costs, are not directly observable but the parameter $x$ in the inventory cost function captures firm characteristics that might be related to these costs. Shirley and Winston (2004), in their econometric specification of the inventory cost function, in addition to the level of inventories have included industry and location dummies to capture variations in these costs due to variations in commodity 
type and geographic location. As Fazel (1997) has argued the size of the firm might also be important as smaller firms have less flexibility in their choice of purchasing methods. ${ }^{9}$

From (4), we get

$$
\frac{d \hat{A}}{d x}=\frac{\int_{A<\hat{A}} v_{12} f(A) d A}{D}<0
$$

Thus firms that face higher inventory costs at the margin will carry less accounts receivable and less accounts payable.

Because of its static framework, our model does not distinguish between stocks and flows. However, our model clearly suggests that any stock of inventories carried forward will have the same marginal effects as $x$. In this case we would write the inventory function as $v\left(I N V_{-1}+\hat{q}-q, x\right)$ where $I N V_{-1}$ denotes lagged inventories. Once more using (4) we get:

$$
\frac{d \hat{A}}{d I N V_{-1}}=\frac{\int_{A<\hat{A}} v_{11} f(A) d A}{D}<0
$$

then our model predicts that firms with a higher stock of inventories will show lower levels of accounts receivable and accounts payable.

\subsection{Changes in Profitability and Risk}

Even firms that operate in the same industry and are of similar size can differ in terms of profitability and have different risk ratings. This could be because of variations in technologies and organization. One way to capture these differences in our model is by allowing for changes in the distribution of the state of the world. A change in the mean keeping the variance the same (so that the distribution with the higher mean dominates the other in the firstorder-stochastic-dominance sense) represents changes in profitability, while a change in the variance keeping the mean the same (mean-preserving spreads) captures changes in riskiness. Once more, it is clear from (4) that the effect of any change in the distribution on accounts payable and expected accounts receivable will be through changes in output and that any change in the distribution will affect accounts payable and expected accounts receivable in the same direction. Actually, we can show that an increase in profitability will have a positive effect on both accounts and an increase in riskiness can have either a positive or a negative effect on the two accounts.

Consider first a change in profitability on (4), keeping $\hat{A}$ at its optimal value before the change. The change subtracts mass from the first integral and adds mass on the second integral having an overall positive effect on the left-hand side of (4). This implies that the optimal value of $\hat{A}$, and thus

\footnotetext{
${ }^{9}$ The inventory control argument employed tells us small firms opt more often for the economic order quantity (EOQ) purchasing option, which requires higher inventories, because they cannot effectively implement the just-in-time (JIT) alternative.
} 
output, must be higher, which in turn implies that both accounts payable and accounts receivable will move up.

Next, consider an increase in riskiness and to ease the exposition suppose that the initial distribution has support on the interval $\left[A_{1}, A_{2}\right]$. Again keeping $\hat{A}$ at its optimal value before the change, the increase in dispersion will have the following effects on (4). It will subtract mass from both integrals that implies a negative effect on the left-hand side of (4) since the value of the two integrals together is positive. It will add mass on the left tail of the first integral and at the margin this effect will decrease the left-hand side of (4) while it will also add mass on the right tail of the second integral which at the margin will increase the left-hand side of (4). Without any further knowledge of the distribution function we cannot determine the sign of the overall effect although it seems that both effects will more likely be negative.

\subsection{Changes in Liquidity}

We have assumed that a firm's level of liquidity affects the cost of both payables and receivables. Here, we consider how changes in liquidity affects the levels of output and trade credit. Once more using (4) we have

$$
\frac{d \hat{A}}{d m}=\frac{-\int_{A>\hat{A}} p(A) r^{\prime \prime} c_{R}^{\prime}(m) f(A) d A-z b^{\prime \prime} c_{P}^{\prime}(m)}{D}>0
$$

So an increase in liquidity has a positive effect on production. Then the effect of a change in liquidity on payables is given by

$$
\frac{d P}{d m}=z \frac{d \hat{q}}{d \hat{A}} \frac{d \hat{A}}{d m}-c_{P}^{\prime}(m) \gtrless 0
$$

and on receivables by

$$
\frac{d E[R]}{d m}=\int_{A>\hat{A}} p(A) f(A) d A \frac{d \hat{q}}{d \hat{A}} \frac{d \hat{A}}{d m}-c_{R}^{\prime}(m) \lessgtr 0
$$

These results capture both the indirect effects of higher liquidity on the two accounts through its influence on their respective costs and the direct effects on cash receipts and cash payments. If the direct effects dominate then higher liquidity will have a negative impact on both accounts.

\section{Empirical Methodology and Data Characteris- tics}

To test the predictions of our model we define our dependent variables AR and AP to represent accounts receivable (defined as the balance sheet item 
trade debtors) and accounts payable (defined as the balance sheet item trade creditors). We explain both trade credit extended and trade credit received with the same independent variables: Stocks $s_{i t}$, the level of finished goods and work in process inventories; Risk $k_{i t}$, which measures the likelihood of company failure in the twelve months following the date of calculation, where a lower value indicates that the firm is more risky. ${ }^{10}$ Profits $s_{i t}$ gives the firm's profit (or loss) for the period, Liquid ${ }_{i t}$ represents firm's gross liquid assets (cash, bank deposits, and other current assets excluding accounts receivables), and Banks $s_{i t}$, which represents short-term bank loans. ${ }^{11}$ With the exception of $R i s k_{i t}$ all variables are scaled by total sales. ${ }^{12}$

We expect the use of trade credit to differ from industry to industry since empirical studies have found wide variations across industries but rather similar credit terms within industries (Burkart et al., 2005; $\mathrm{Ng}$ et al., 1999; Nilsen, 2002). At the same time, the reliance of firms on internal finance relative to external finance follows an industry pattern. In addition, as Shirley and Winston (2004) suggest, inventory costs differ significantly across industries. This is why we allocate firms to one of the following nine manufacturing industrial sectors: metals and metal goods; other minerals, and mineral products; chemicals and man made fibres; mechanical engineering; electrical and instrument engineering; motor vehicles and parts, other transport equipment; food, drink, and tobacco; textiles, clothing, leather, and footwear; and others (Blundell et al., 1992). In our specifications, we control for the industry characteristics by including industry dummies interacted with time dummies. Thus the inventory costs can differ between industries and across time.

In order to check whether the sensitivity of trade credit usage (both extended and received) differs at firms with different size, which also affects the costs of holding inventories (Fazel, 1997), we define the variable Si $z e_{i t}$ as the logarithm of firm's real assets. We then interact it with the Stocks $s_{i t}$ variable to control for cost differences in holding inventories. We postulate that holding costs decrease with the level of inventories but also with the size of the firm. Therefore, the estimated equations take the following form:

\footnotetext{
${ }^{10}$ We are using the quiscore indicator produced by Qui Credit Assessment Ltd, which measures the likelihood of company failure in the twelve months following the date of calculation. Quiscore is given as a number in the range from 0 to 100 . The lower its quiscore the more risky a firm is likely to be. This is a wider definition of perceived financial health than the commonly used bond rating, which only applies to rated firms (Whited, 1992; Kashyap and Stein, 1994).

${ }^{11}$ We include the latter variable in our specifications as we think that firms' use of trade credit relies heavily on their use of bank loans even though our theoretical model has concentrated on trade credit only. We extend the theoretical model to include bank loans and explain our empirical results in the appendix.

${ }^{12}$ Exact data definitions are given in the appendix.
} 


$$
\begin{aligned}
\frac{\text { AR }_{i t}}{\text { Sales }_{i t}}= & \alpha_{i}+\frac{\text { Stocks }_{i t}}{\text { Sales }_{i t}} \beta_{1}+\frac{\text { Stocks }_{i t}}{\text { Sales }_{i t}} * \text { Si } z e_{i t} \beta_{2}+\text { Risk }_{i t} \beta_{3}+ \\
& \frac{\text { Profits }_{i t}}{\text { Sales }_{i t}} \beta_{4}+\frac{\text { Liquid }_{i t}}{\text { Sales }_{i t}} \beta_{5}+\frac{\text { Banks }_{i t}}{\text { Sales }_{i t}} \beta_{6}+\operatorname{Si} z e_{i t} \beta_{7}+e_{i t}
\end{aligned}
$$

and

$$
\begin{aligned}
\frac{\text { AP }_{i t}}{\text { Sales }_{i t}=} & \alpha_{i}+\frac{\text { Stocks }_{i t}}{\text { Sales }_{i t}} \gamma_{1}+\frac{\text { Stocks }_{i t}}{\text { Sales }_{i t}} * \text { Si } z e_{i t} \gamma_{2}+\text { Risk }_{i t} \gamma_{3}+ \\
& \frac{\operatorname{Pr} \text { ofits }_{i t}}{\text { Sales }_{i t}} \gamma_{4}+\frac{\text { Liquid }_{i t}}{\text { Sales }_{i t}} \gamma_{5}+\frac{\text { Banks }_{i t}}{\text { Sales }_{i t}} \gamma_{6}+\operatorname{Si} z e_{i t} \gamma_{7}+u_{i t}
\end{aligned}
$$

where $\alpha_{i}$ is a firm-specific component, $\beta_{i}$ 's and $\gamma_{i}$ 's are coefficient values, and $e_{i t}$ and $u_{i t}$ are the respective idiosyncratic error component. We control for firm-specific, time-invariant effects, and for the possible endogeneity of the regressors, by using a first-difference GMM approach. ${ }^{13}$ Lags of each of the regressors (including the interaction terms) are used as instruments. ${ }^{14}$ Both time dummies and industry dummies interacted with time dummies are included in all our regressions. We report both the first- $(\mathrm{m} 1)$ and the second-order $(\mathrm{m} 2)$ test for serial correlation, which are asymptotically distributed as a standard normal under the null of no serial correlation of the differenced residuals. At the same time, the variables in the instrument set should be uncorrelated with the error term in the relevant equation if the model is correctly specified. We report the Sargan (Hansen) test for the legitimacy of variables dated t-2 as instruments in the differenced equation. Under the null of instrument validity the Sargan test for overidentifying restrictions is asymptotically distributed as a chi-square with degrees of freedom equal to the number of instruments less the number of parameters.

Our dataset is derived from the profit and loss and balance sheet data gathered by Bureau Van Dijk Electronic Publishing in the FAME database, which provides information on companies over a ten year period. Our sample includes firms operating in the manufacturing sector and covers the period 1993 - 2003. The majority (over ninety-nine percent) of the firms included in the dataset are not traded on the stock market. The large proportion of unquoted firms means we are likely to observe many firms that are financially constrained i.e. they are unable to obtain resources from capital markets and possibly also banks to purchase inputs for production. Therefore the relevant consideration for these firms is the opportunity to purchase goods at the margin financed by additional trade credit or bank loans. We excluded

\footnotetext{
${ }^{13}$ All our regressions are performed in Stata using the command xtabond2 developed by Roodman (2005).

${ }^{14}$ This is the reason why the size of the sample in the tables of results is smaller than the full sample.
} 
companies that changed the date of their accounting year-end by more than a few weeks so that the data refer to 12 month accounting periods. We excluded observations in the 1 percent tails for each of the regression variables to control for the potential influence of outliers. Table 1 reports summary statistics.

\subsection{Empirical Results}

Tables 2 and 3 report the relationship between accounts receivable (AR) and accounts payable (AP) for firms in our panel and their characteristics. Column 1 in both tables presents regression results ignoring the influence of $\mathrm{Si} z e_{i t}$ while the remaining columns include $\mathrm{Si} z e_{i t}$ as an additional variable (column 2), as an interaction term with Stocks $s_{i t}$ (column 3) and both as an additional variable and an interaction term (column 4).

The level of inventories is predicted to have a direct negative affect on $\mathrm{AR}$, and an indirect negative affect on AP from our model. Here production decisions are critical, since when production exceeds sales causing inventories to increase, other things equal, firms will have an incentive to offer more trade credit in order to gain more total sales and hold fewer inventories. The argument is similar to the sales motive identified by Wilson and Summers (2002), where firms extend sales by offering goods on account in the first instance. Our results show that inventories have a large, negative and significant impact on AR and a negligible impact on AP.

As proposed in the model, there are interactions that influence the scale of the impact of inventory holding costs. The most important of these is the size of the firm, which has an impact on both AR and AP. Larger firms both extend and receive more trade credit to and from their business partners (even after scaling by sales) and they also have lower inventory holding costs within the same industry other things equal. The levels of AR and AP divided by sales increase with the size of the firm since the additional size variable is significant and positive in both regressions (column 2, Tables 2 and 3) and when we interact the Stocks variable with the measure for size (columns 3 and 4, Tables 2 and 3 ) it becomes apparent that as the size of the firm increases, stocks of inventories play a lesser role in the firm's decision to extend AR since the positive coefficient of the interacted term offsets the negative effect of stocks on AR (column 3, Table 2). In terms of the tradeoff between avoiding holding costs of inventories and obtaining future cash sales, the cost of holding stocks is lower for larger firms. As before, AP are not influenced by the firm's stocks of inventories and our other results do not change when we drop this variable from the regression (column 4, Table $3)$.

Risk, profitability and liquidity have an indirect influence on AR and AP through the level of production and inventories. Our model predicts profitability will increase both AR and AP, but the signs of risk and liquid- 
ity are not determined. However, as we remarked earlier we have reasons to think that our Risk variable might have a negative impact on both AR and $\mathrm{AP}$ and this is what our empirical results suggest. We have found a negative relationship between liquidity and trade credit extended, and this is consistent with Peterson and Rajan (1997), who also found a negative relationship between AR and liquidity. Profitability has a positive effect since extra profit can be channeled towards AR, and trade credit is more likely to be offered to profitable firms. The common sign pattern is supported in our results and profitability is positive in both AR and AP regressions. These firm-specific characteristics were also found to be important in determining access to bank loans in Bougheas, Mizen and Yalcin (2006) but our contribution here is to show that besides indirectly influencing AP by relaxing credit limits from banks, they have direct effects on AP and AR through inventories since the firm faces a trade-off between incurring holding costs of inventories with the possibility of future cash sales versus sales on credit now.

We introduce the variable $B a n k s_{i t}$ as a control variable to determine the effect of bank loans on AR and AP. We find that it increases AR and reduces $\mathrm{AP}$, which is consistent with the pecking order of finance view, which assumes that trade credit is more expensive than bank loans. The idea that trade credit is lower down the pecking order of finance has been supported by Petersen and Rajan (1997) who find evidence that US firms increase AP when credit is rationed i.e. there is restricted access to bank loans and capital markets. It is also consistent with the assumptions of Burkart, Ellingsen and Giannetti (2005). We offer a theoretical extension to our model that explains how our findings can be embedded in our model in the Appendix, although it is a secondary consideration in relation to the role of inventories.

To summarize, our theoretical model explains the decision process of the firm, which derives optimal production and sales subject to the state of the world. This indicates how AR and AP respond to changes in output as the state of the world improves, and risk, profitability and liquidity as well as bank loans impinge on this state of the world, affecting production and inventories, and therefore alter the levels of AP and AR. This is the inventory channel of trade credit which we confirm empirically.

Our final analysis involves exploration of the robustness of our results. We consider firms that are relatively large or small in relation to others in their industry by defining a dummy variable Large which takes value 1 in a given year if the firm's total assets are in the top 25 percentile of the distribution of the total assets of all the firms in that particular industry and year. By contrast small firms are in the remainder of the distribution. We allow firms to transit between categories and we also acknowledge that firm size is measured specifically for each industry. The cut-off value is decided by the distribution of the firms in our sample reported in Table 1b, where 
centile values for real assets are displayed. This underlines the fact that our dataset mainly comprises small firms.

In Table 4 we first investigate the effects of the Large dummy on the level of AR and AP. We find that large firms extend more AR and more $\mathrm{AP}$, as indicated by a positive and significant coefficient (columns 1, 3 and 4, Table 4). Then by interacting the Large and Small = (1-Large) dummies with $S t o c k s_{i t}$ we determine whether inventories play a greater (lesser) role on AR and AP for large (small) firms. We find that firms that are relatively large compared to other firms in the same industry and year respond less to inventories than do small firms. This clarifies the point that relatively large firms are less influenced by the trade-off between current credit sales and future cash sales because their holding costs are lower. These results are robust to the choice of the cut-off level and are practically identical in terms of signs, and relative magnitudes, when setting the cut-off value at the 50th percentile, 70th percentile, and 80th percentile.

The results are qualitatively the same when we reconsider our analysis using data only for the unquoted firms, as they constitute the majority of the firms in our sample. Results are also qualitatively the same when we eliminate from the analysis the larger public firms. Finally, including only time dummies in the instrument matrix and leaving out industry dummies interacted with time dummies produces similar results. ${ }^{15}$

\section{Conclusions}

We develop a simple theoretical model with a stochastic demand framework that captures the trade-off between inventories and trade credit. The essential elements are that the firm is in the middle of a credit chain, and produces goods for sale, holds inventories of goods that were produced but unsold at a cost and in the face of uncertain demand for its products extends trade credit to its financially constrained customers to obtain additional sales. Our model provides directly testable predictions to identify the response of accounts payable and accounts receivable to changes in the cost of inventories, profitability, risk and liquidity, and importantly, this influence operates through a production channel. Even the influence of bank loans on trade credit operates by allowing greater production, inventories and ultimately sales financed in part through credit. We directly test the predictions of our model using GMM estimates in first differences on an unbalanced panel of UK firms drawn from FAME that includes larger FTSE-quoted firms and those on the smaller AIM/OFEX exchange, as well as unquoted firms. Our results support the model suggesting that there is an inventory channel of trade credit, complement many existing studies focusing on the financial terms of trade credit.

\footnotetext{
${ }^{15}$ These results are not reported but are available on request.
} 


\section{Appendix 1: Introducing Bank Loans}

In order to concentrate on the trade-off between trade credit and inventories we ignore any other forms of finance available to firms when we developed our theoretical model, and we assume with Peterson and Rajan (1997) and Burkart and Ellingsen (2004) that bank credit is cheaper than trade credit. We also assume the firm faces a bank credit limit $\bar{L}$, which may be related to credit constraints arising from asymmetric information or any other cause, and we denote by $L$ the amount actually borrowed. Then under the supposition that bank loans are cheaper than trade credit for a given maturity we have

$$
L=\min \left\{z q(\hat{A})-c_{P}(m), \bar{L}\right\}
$$

Thus, the firm exhausts its bank credit limit before it seeks credit from its suppliers. ${ }^{16}$ accounts payable now are

$$
P \equiv z q(\hat{A})-c_{P}(m)-L
$$

For firms that are not financially constrained, $L<\bar{L}$, increasing the bank credit limit will not affect any of their decisions. In contrast, for financially constrained firms, $L=\bar{L}$, an increase in the bank credit limit will have the following effects:

$$
\frac{d \hat{A}}{d \bar{L}}=\frac{-z b^{\prime \prime}}{D}>0
$$

Production will increase and thus accounts receivable will also increase. In contrast, we have

$$
\frac{d P}{d \bar{L}}=z \frac{d \hat{q}}{d \hat{A}} \frac{d \hat{A}}{d \bar{L}}-1
$$

So accounts receivable are complements to bank loans but accounts payable can be either complements or substitutes.

\footnotetext{
${ }^{16}$ To keep things simple we have assumed that the limit is exogenous. Following recent developments suggest that the credit limit is increasing in tangible assets, $T$, and decreasing in existing debt, D, (Bougheas, Mizen and Yalcin, 2005), increasing in past accounts receivable as being one of the assets that banks are willing to accept as collateral (Mian and Smith, 1997 and Burkart and Ellingsen, 2004) and past accounts payable following Biais and Gollier (1997) and Burkart and Ellingsen (2004) who argue that the willingness of firms to supply trade credit provides a signal to banks that the borrower is creditworthy.
} 


\section{Appendix 2: Definitions of the variables used}

Accounts receivable: defined as the ratio of the balance sheet item trade debtors and the firm's total sales.

Accounts payable: defined as the ratio of balance sheet item trade creditors and the firm's total sales.

Stocks: includes finished goods and work-in-process inventories scaled by the firm's total sales.

Risk: we are using the quiscore indicator produced by Qui Credit Assessment Ltd, which measures the likelihood of company failure in the twelve months following the date of calculation. Quiscore is given as a number in the range from 0 to 100 . The lower its quiscore the more risky a firm is likely to be. The indicator is constructed taking into account a number of factors, including the presence of any adverse documents appearing against the company on the public file, and the timeliness of getting the accounts filed. However, the most important factors relate to the financial performance of the company as evidenced by its balance sheet and profit and loss accounts. The key financial items used include turnover, pre-tax profits, working capital, intangibles, cash and bank deposits, creditors, bank loans and overdrafts, current assets, current liabilities, net assets, fixed assets, share capital, reserves and shareholders funds. The underlying economic conditions are also taken into account.

Profits: gives the firm's profit (or loss) for the period scaled by the firm's total sales.

Liquid: represents firm's gross liquid assets (cash, bank deposits, and other current assets excluding accounts receivable)

Banks: represents short-term debt scaled by the firm's total sales. Shortterm debt includes the following items: bank overdrafts, short-term group and director loans, hire purchase, leasing, and other short-term loans, but it is predominantly bank finance.

Size: is the logarithm of firm's total real assets.

Total assets: the sum of the firm's fixed and current assets.

Deflators: total assets are deflated using the aggregate GDP deflator.

Large: dummy variable which takes value 1 in a given year if the firm's total assets are in the top 25 percentile of the distribution of the total assets of all the firms in that particular industry and year. By contrast small firms are in the remainder of the distribution. Thus firms are allowed to transit between categories.

Quoted: firms are quoted if they are traded either on the stock exchange, or on the smaller AIM / OFEX exchange. The remainder of the firms are unquoted. Firms are assumed not to change category during time.

Public: firms traded on any exchange and public firms not traded at all. 


\section{References}

[1] Alphonse, P., J. Ducret and E. Severin (2003) "When trade credit facilitates access to bank finance: Evidence from US small business data", mimeo University of Lille.

[2] Atanasova, C., Wilson, N., (2004). "Disequilibrium in the UK corporate loan market," Journal of Banking and Finance 28, 595-614.

[3] Biais, B. and C. Gollier (1997) "Trade credit and credit rationing," Review of Financial Studies 10, 903-37

[4] Blundell, R., S. Bond, M. Devereux and F. Schiantarelli (1992) "Investment and Tobin's Q: evidence from company panel data," Journal of Econometrics $31,233-57$

[5] Bougheas S., P. Mizen and C. Yalcin (2006) "Access to external finance: theory and evidence on the impact of monetary policy and firm-specific characteristics," Journal of Banking and Finance 30, 199-227

[6] Brennan, M., V. Maksimovic and J. Zechner (1988) "Vendor financing," Journal of Finance 43, 1127-41

[7] Burkart, M. and T. Ellingsen (2004) "In-kind finance: a theory of trade credit," American Economic Review 94, 569-90

[8] Burkart, M., T. Ellingsen and M. Giannetti (2005) "What you sell is what you lend? Explaining trade credit contracts," ECGI Finance Working Paper No $71 / 2005$

[9] Cunat, V.M. (2007) "Trade credit: suppliers as debt collectors and insurance providers," Review of Financial Studies 20, 2, 491-527

[10] Cunningham, R. (2004) "Trade credit and credit rationing in Canadian firms," Bank of Canada Working Paper 2004-49

[11] Daripa, A. and J. Nilsen (2005) "Subsidizing inventory: a theory of trade credit and repayment," Birkbeck Working Papers in Economics and Finance No. 0522

[12] Demirguc-Kunt, A. and V. Maksimovic (2002) "Firms as financial intermediaries: evidence from trade credit data," Working Paper, University of Maryland

[13] Emery, G. (1987) "An optimal financial response to variable demand," Journal of Financial and Quantitative Analysis 22, 209-25 
[14] Fazel, F. (1997) "A comparative ananlysis of inventory costs of JIT and EOQ purchasing," International Journal of Physical Distribution \& Logistics Management 27, 496-504

[15] Ferris, S. (1981) "A transactions theory of trade credit use," Quarterly Journal of Economics 94, 243-70

[16] Fisman, R. and I. Love (2003) "Trade credit, financial intermediary development and industry growth," Journal of Finance 58, 353-74

[17] Frank, M. and V. Maksimovic (1998) "Trade credit, collateral, and adverse selection," Working Paper, University of Maryland

[18] Giannetti, M. (2003) "Do better institutions mitigate agency problems? Evidence from corporate finance choices," Journal of Financial and Quantitative Analysis 38, 185-212

[19] Guariglia, A. and S. Mateut (2006) "Credit channel, trade credit channel, and inventory investment: Evidence from a panel of UK firms," Journal of Banking and Finance 30, 2835-2856.

[20] Jain, N. (2001) "Monitoring costs and trade credit," Quarterly Review of Economics and Finance 41, 89-110

[21] Kashyap, A. and J. Stein (1994) "Monetary policy and bank lending," in G. Mankiw (ed.) Monetary Policy, The University of Chicago Press, Chicago

[22] Kohler, M., E. Britton, and T. Yates (2000) "Trade credit and the monetary transmission mechanism", Bank of England working paper No.

[23] Lee, Y. and J. Stove (1993) "Product risk, asymmetric information, and trade credit," Journal of Financial and Quantitative Analysis 28, 285-300

[24] Long, M., I. Malitz and A. Ravid (1993) "Trade credit, quality guarantees and product marketability," Financial Management 22, 117-27

[25] Love, I., L. Preve and V. Sarria-Allende (2005) "Trade credit and bank credit: evidence from recent financial crises," World Bank Policy Research Working Paper 3716

[26] Mateut, S., S. Bougheas and P. Mizen (2006) "Trade credit, bank lending and monetary policy transmission" European Economic Review, 50, 603-29.

[27] Mian, S. and C. Smith (1992) "Accounts receivable management," Journal of Finance 47, 169-200

[28] Nadiri, M. (1969) "The determinants of trade credit in U.S. total manufacturing sector," Econometrica 37, 408-23 
[29] Ng, C., J. Smith and R. Smith (1999) "Evidence on the determinants of credit terms in interfirm trade," Journal of Finance 54, 1109-29

[30] Nilsen, J. (2002) "Trade credit and the bank lending channel," Journal of Money, Credit and Banking 34, 226-53

[31] Petersen, M. and R. Rajan (1997) "Trade credit: theories and evidence", Review of Financial Studies 10, 661-97

[32] Preve, L.A. (2003) "Financial distress and trade credit: an empirical analysis", mimeo, University of Texas, Austin.

[33] Rajan, R.G. and L. Zingales (1995) "What do we know about capital structure? Some evidence from international data", Journal of Finance 50, 1421-60

[34] Robb, D. and E. Silver (2006) "Inventory management under date-terms supplier trade credit with stochastic demand and lead time", Journal of Operational Research 57, 692-702

[35] Roodman, D. 2005. "xtabond2: Stata module to extend xtabond dynamic panel data estimator", Center for Global Development, Washington. http://econpapers.repec.org/software/bocbocode/s435901.htm

[36] Schwartz, R. (1974) "An economic model of trade credit," Journal of Financial and Quantitative Analysis 9, 643-57

[37] Shirley, C. and C. Winston (2004) "Firm inventory behavior and the returns from highway infrastructure investment," Journal of Public Economics 55, $398-415$

[38] Smith, J. (1987) "Trade credit and informational asymmetry," Journal of Finance 42, 863-69

[39] Whited, T. (1992) "Debt, liquidity constraints and corporate investment: Evidence from panel data," Journal of Finance 47, 1425-60

[40] Wilner, B. (2000) "The exploitation of relationships in financial distress: the case of trade credit," Journal of Finance 55, 153-78

[41] Wilson, N. and B. Summers (2002) "Trade credit terms offered by small firms: survey and empirical evidence," Journal of Business, Finance and Accounting $29,317-51$ 


\section{Appendix}

Table 1. Summary statistics (mean and standard deviations)

\begin{tabular}{l|c|cc|cc|cc|}
\hline Variable & $\begin{array}{c}\text { Whole } \\
\text { sample }\end{array}$ & $\begin{array}{c}\text { Small } \\
\text { Bottom } \\
75 \%\end{array}$ & $\begin{array}{c}\text { Large } \\
\text { Top 25\% }\end{array}$ & $\begin{array}{c}\text { Small } \\
\text { Bottom } \\
50 \%\end{array}$ & $\begin{array}{c}\text { Large } \\
\text { Top 50\% }\end{array}$ & $\begin{array}{c}\text { Small } \\
\text { Bottom } \\
25 \%\end{array}$ & $\begin{array}{c}\text { Large } \\
\text { Top 75\% }\end{array}$ \\
\hline TD & 0.171 & 0.176 & 0.157 & 0.176 & 0.166 & 0.174 & 0.171 \\
TC & $(0.078)$ & $(0.077)$ & $(0.077)$ & $(0.078)$ & $(0.077)$ & $(0.078)$ & $(0.077)$ \\
Stocks & 0.107 & 0.108 & 0.101 & 0.109 & 0.104 & 0.109 & 0.106 \\
& $(0.062)$ & $(0.062)$ & $(0.059)$ & $(0.063)$ & $(0.061)$ & $(0.063)$ & $(0.061)$ \\
Risk & 0.121 & 0.118 & 0.131 & 0.112 & 0.130 & 0.102 & 0.128 \\
& $(0.089)$ & $(0.089)$ & $(0.088)$ & $(0.087)$ & $(0.090)$ & $(0.082)$ & $(0.090)$ \\
Profits & 0.540 & 0.535 & 0.557 & 0.525 & 0.556 & 0.507 & 0.551 \\
& $(0.214)$ & $(0.212)$ & $(0.220)$ & $(0.209)$ & $(0.218)$ & $(0.207)$ & $(0.215)$ \\
Liquid & 0.031 & 0.029 & 0.036 & 0.028 & 0.034 & 0.028 & 0.032 \\
& $(0.075)$ & $(0.071)$ & $(0.087)$ & $(0.070)$ & $(0.080)$ & $(0.070)$ & $(0.077)$ \\
Banks & 0.155 & 0.131 & 0.225 & 0.116 & 0.194 & 0.100 & 0.173 \\
& $(0.203)$ & $(0.177)$ & $(0.254)$ & $(0.160)$ & $(0.231)$ & $(0.145)$ & $(0.216)$ \\
Size & 0.152 & 0.135 & 0.201 & 0.125 & 0.179 & 0.115 & 0.164 \\
& $(0.195)$ & $(0.168)$ & $(0.253)$ & $(0.151)$ & $(0.228)$ & $(0.138)$ & $(0.209)$ \\
& 8.695 & 8.044 & 10.654 & 70.587 & 90.805 & 70.074 & 90.237 \\
& $(1.483)$ & $(0.892)$ & $(1.144)$ & $(0.688)$ & $(10.210)$ & $(0.559)$ & $(10.287)$ \\
\hline Observations & 72905 & 54714 & 18191 & 36477 & 36428 & 18267 & 54638 \\
\hline
\end{tabular}

Note: TD represents trade debit (account receivables) and TC represents trade credit (account payables). Stocks stands for stocks of inventories; Risk measures the likelihood of company failure in the twelve months following the date of calculation, where a lower value indicates that the firm is more risky. Profits gives the firm's profit (or loss) for the period; Liquid represents firm's liquid assets (cash, bank deposits, and other current assets), Banks represents short-term bank loans. Size is the logarithm of total real assets. With the exception of Risk and Size all variables are scaled by total sales. We separate firms into two size categories using a dummy variable for size named Large, which takes value 1 in a given year if the firm's total assets are in the top 25 (columns 2-3), top 50 (columns 4-5), and top 75 (columns 6-7) percentile of the distribution of total assets of all the firms in that particular industry and year. Thus firms are allowed to transit between categories.

Table 1b. Centile values for real assets

\begin{tabular}{l|cc}
\hline Variable & Percentile & Centile \\
\hline Real assets & 1 & 361.753 \\
& 25 & 2163.765 \\
& 50 & 4797.402 \\
& 75 & 13244.19 \\
\hline & 99 & 515488.6 \\
\hline
\end{tabular}


Table 2. Accounts receivables (AR)

\begin{tabular}{|c|c|c|c|c|}
\hline & 1 & 2 & 3 & 4 \\
\hline \multirow[t]{2}{*}{ Stocks } & $-0.369 * * *$ & $-0.554 * * *$ & $-1.066 * *$ & $-1.444 * * *$ \\
\hline & $(0.119)$ & $(0.146)$ & $(0.415)$ & $(0.547)$ \\
\hline \multirow[t]{2}{*}{ Stocks*Size } & & & $0.085^{* *}$ & $0.109^{*}$ \\
\hline & & & $(0.040)$ & $(0.061)$ \\
\hline \multirow[t]{2}{*}{ Risk } & $-0.138 * * *$ & $-0.210 * * *$ & $-0.148 * * *$ & $-0.203 * * *$ \\
\hline & $(0.029)$ & $(0.037)$ & $(0.030)$ & $(0.036)$ \\
\hline \multirow[t]{2}{*}{ Profits } & $0.268 * * *$ & $0.493 * * *$ & $0.284 * * *$ & $0.488 * * *$ \\
\hline & (0.104) & $(0.099)$ & $(0.100)$ & $(0.094)$ \\
\hline \multirow[t]{2}{*}{ Liquid } & $-0.091 * *$ & -0.071 & $-0.120 * * *$ & $-0.082 *$ \\
\hline & $(0.043)$ & $(0.051)$ & $(0.039)$ & $(0.044)$ \\
\hline \multirow[t]{2}{*}{ Banks } & $0.099 * * *$ & $0.097 * *$ & $0.083 * * *$ & $0.091 * *$ \\
\hline & $(0.033)$ & $(0.041)$ & $(0.031)$ & $(0.037)$ \\
\hline \multirow[t]{2}{*}{ Size } & & $0.030 * * *$ & & 0.019 \\
\hline & & $(0.009)$ & & $(0.013)$ \\
\hline Observations & 56432 & 56432 & 56432 & 56432 \\
\hline No of firms & 10877 & 10877 & 10877 & 10877 \\
\hline $\mathrm{m} 1(\mathrm{p})$ & 0.00 & 0.00 & 0.00 & 0.00 \\
\hline $\mathrm{m} 2(\mathrm{p})$ & 0.19 & 0.69 & 0.18 & 0.71 \\
\hline Hansen/Sargan (p) & 0.24 & 0.39 & 0.33 & 0.44 \\
\hline
\end{tabular}

Notes: All specifications are estimated using a GMM first-difference specification. Test statistics and standard errors (in parentheses) are asymptotically robust to heteroskedasticity. $\mathrm{ml}(\mathrm{m} 2)$ is a test for first- (second-) order serial correlation in the first-differenced residuals, asymptotically distributed as $\mathrm{N}(0,1)$ under the null of no serial correlation. The Hansen/Sargan test is a test of the overidentifying restrictions, distributed as chi-square under the null of instrument validity. Instruments include Stocks $_{i, t-2}$; Stocks $_{i, t-2} *$ Size $_{i, t-2} ;$ Risk $_{i, t-2} ;$ Profit $_{i, t-2} ;$ Liquidity $_{i, t-2} ;$ Banks $_{i, t-2}$; and further lags. Time dummies and time dummies interacted with industry dummies were always included as regressors and as instruments. *, **, *** indicate significance at the 10,5 , and 1 percent level, respectively. 
Table 3. Accounts payables (AP)

\begin{tabular}{l|cccc}
\hline & 1 & 2 & 3 & 4 \\
\hline Stocks & -0.038 & -0.109 & 0.035 & \\
Stocks*Size & $(0.079)$ & $(0.092)$ & $(0.273)$ & \\
& & & -0.004 & \\
Risk & & $0.026)$ & $-0.224^{* * *}$ \\
& $-0.167^{* * *}$ & $-0.200^{* * *}$ & $-0.157^{* * *}$ & $(0.036)$ \\
Profits & $(0.028)$ & $(0.035)$ & $(0.026)$ & $0.361^{* * *}$ \\
& $0.231^{* * *}$ & $0.344^{* * *}$ & $0.180^{* * *}$ & $(0.078)$ \\
Liquid & $(0.078)$ & $(0.076)$ & $(0.069)$ & $0.079^{* *}$ \\
& $0.072^{* * *}$ & $0.089^{* * *}$ & $0.045^{*}$ & $(0.032)$ \\
Banks & $(0.027)$ & $(0.031)$ & $(0.023)$ & $-0.167^{* * *}$ \\
& $-0.109 * * *$ & $-0.116^{* * *}$ & $-0.104 * * *$ & $(0.045)$ \\
Size & $(0.033)$ & $(0.040)$ & $(0.030)$ & $0.018^{* * *}$ \\
& & $0.016 * *$ & & $(0.007)$ \\
\hline Observations & & $(0.006)$ & & 55848 \\
No of firms & 55848 & 55848 & 55848 & 10806 \\
m1(p) & 10806 & 10806 & 10806 & 0.00 \\
m2(p) & 0.00 & 0.00 & 0.00 & 0.14 \\
\hline Hansen/Sargan(p) & 0.44 & 0.19 & 0.62 & 0.86 \\
\hline
\end{tabular}

Notes: All specifications are estimated using a GMM first-difference specification. Test statistics and standard errors (in parentheses) are asymptotically robust to heteroskedasticity. $m l(m 2)$ is a test for first- (second-) order serial correlation in the first-differenced residuals, asymptotically distributed as $\mathrm{N}(0,1)$ under the null of no serial correlation. The Hansen/Sargan test is a test of the overidentifying restrictions, distributed as chi-square under the null of instrument validity. Instruments include Stocks $_{i, t-2}$; Stocks $_{i, t-2} *$ Size $_{i, t-2} ;$ Risk $_{i, t-2} ;$ Profit $_{i, t-2} ;$ Liquidity $_{i, t-2} ;$ Banks $_{i, t-2}$; and further lags. Time dummies and time dummies interacted with industry dummies were always included as regressors and as instruments. *, **, *** indicate significance at the 10,5 , and 1 percent level, respectively. 


\section{Table 4. Robustness results}

Results for accounts receivables (AR) are presented in columns 1-2 and for accounts payables (AP) in columns 3-5. Instead of using the continuous variable Size, we consider the situation of each firm relative to that of other firms in the industry in which that firm operates and for each year. We define a dummy variable for size named Large, which takes value 1 in a given year if the firm's total assets are in the top 25 percentile of the distribution of total assets of all the firms in that particular industry and year. This way we allow firms to transit between categories. We then interact Stocks with (1-Large) and Large to capture the impact of costs of holding inventories separately for small and large firms.

\begin{tabular}{|c|c|c|c|c|c|}
\hline & \multicolumn{2}{|c|}{ AR } & \multicolumn{3}{|c|}{ AP } \\
\hline & 1 & 2 & 3 & 4 & 5 \\
\hline Stocks & $\begin{array}{c}-0.375 * * * \\
(0.119)\end{array}$ & & $\begin{array}{l}-0.041 \\
(0.080)\end{array}$ & & \\
\hline Stocks*Small & & $\begin{array}{c}-0.354 * * * \\
(0.124)\end{array}$ & & & $\begin{array}{l}-0.012 \\
(0.083)\end{array}$ \\
\hline Stocks*Large & & $\begin{array}{c}-0.226 * * \\
(0.103)\end{array}$ & & & $\begin{array}{l}-0.064 \\
(0.066)\end{array}$ \\
\hline Risk & $\begin{array}{c}-0.138 * * * \\
(0.029)\end{array}$ & $\begin{array}{c}-0.134 * * * \\
(0.028)\end{array}$ & $\begin{array}{c}-0.166 * * * \\
(0.028)\end{array}$ & $\begin{array}{c}-0.184 * * * \\
(0.029)\end{array}$ & $\begin{array}{c}-0.159 * * * \\
(0.027)\end{array}$ \\
\hline Profits & $\begin{array}{c}0.273 * * * \\
(0.103)\end{array}$ & $\begin{array}{c}0.241^{* *} \\
(0.096)\end{array}$ & $\begin{array}{c}0.234 * * * \\
(0.078)\end{array}$ & $\begin{array}{c}0.251 * * * \\
(0.083)\end{array}$ & $\begin{array}{c}0.177 * * * \\
(0.069)\end{array}$ \\
\hline Liquid & $\begin{array}{c}-0.088 * * \\
(0.043)\end{array}$ & $\begin{array}{c}-0.105 * * * \\
(0.039)\end{array}$ & $\begin{array}{c}0.072 * * * \\
(0.027)\end{array}$ & $\begin{array}{c}0.071 * * \\
(0.028)\end{array}$ & $\begin{array}{c}0.056 * * \\
(0.024)\end{array}$ \\
\hline Banks & $\begin{array}{c}0.098 * * * \\
(0.033)\end{array}$ & $\begin{array}{c}0.089 * * * \\
(0.031)\end{array}$ & $\begin{array}{c}-0.109 * * * \\
(0.033)\end{array}$ & $\begin{array}{c}-0.141 * * * \\
(0.036)\end{array}$ & $\begin{array}{c}-0.104 * * * \\
(0.031)\end{array}$ \\
\hline Large & $\begin{array}{c}0.013 * * * \\
(0.003)\end{array}$ & & $\begin{array}{c}0.006^{* *} \\
(0.002)\end{array}$ & $\begin{array}{c}0.006 * * \\
(0.003)\end{array}$ & \\
\hline Observations & 56432 & 56432 & 55848 & 55848 & 55848 \\
\hline No of firms & 10877 & 10877 & 10806 & 10806 & 10806 \\
\hline $\mathrm{m} 1(\mathrm{p})$ & 0.00 & 0.00 & 0.00 & 0.00 & 0.00 \\
\hline $\mathrm{m} 2(\mathrm{p})$ & 0.22 & 0.16 & 0.41 & 0.38 & 0.69 \\
\hline Hansen/Sargan(p) & 0.25 & 0.37 & 0.54 & 0.82 & 0.19 \\
\hline
\end{tabular}

Notes: All specifications are estimated using a GMM first-difference specification. Test statistics and standard errors (in parentheses) are asymptotically robust to heteroskedasticity. $\mathrm{ml}(\mathrm{m} 2)$ is a test for first- (second-) order serial correlation in the first-differenced residuals, asymptotically distributed as $\mathrm{N}(0,1)$ under the null of no serial correlation. The Hansen/Sargan test is a test of the overidentifying restrictions, distributed as chi-square under the null of instrument validity. Instruments include Stocks $_{i, t-2} ;$ Stocks $_{i, t-2}{ }^{*}$ Small $_{i, t-2} ;$ Stocks $_{i, t-2}{ }^{*}$ Large $_{i, t-2} ;$ Risk $_{i, t-2} ;$ Profit $_{i, t-2} ;$ Liquidity $_{i, t-2} ;$ Banks $_{i, t-2}$; and further lags. Time dummies and time dummies interacted with industry dummies were always included as regressors and as instruments. *, **, *** indicate significance at the 10,5 , and 1 percent level, respectively. 